\title{
Time-depending solubility of different fixed prosthetic permanent luting cements
}

\author{
Nikola Gigovski ${ }^{1}$ *, Vesna Korunoska Stevkovska ${ }^{1}$, Aneta Mijoska ${ }^{1}$, \\ Sanja Pancevska ${ }^{1}$, Emilija Valjakova Bajraktarova ${ }^{1}$, Ana Gigovska Arsova ${ }^{2}$ \\ ${ }^{I}$ Department for Prosthetic Dentistry, Faculty for Dental Medicine, \\ Ss. Cyril \& Methodius University, Majka Tereza 4, 1000 Skopje, R. Macedonia \\ ${ }^{2}$ Dental Practice "Denta Nova", Debarca 70, 1000 Skopje, R. Macedonia
}

Received: September 2017; Accepted: November 2017

\begin{abstract}
The solubility of dental cements is important property due to their prolonged exposure to oral fluids. The recommended standard is $0.2 \%$ mass loss for 24 hours.

The aim of the study is to measure and compare the values of the solubility in different types of permanent cements as a function of time of exposure to the solvent.

Four types of cements were selected: zinc phosphate (ZP), glass-ionomer (GI), resin-modified glass-ionomer (RG) and polycarboxylate (PC) cement. Totally 120 samples, equally divided in 4 series, were fabricated according to the experimental method recommended for in vitro laboratory measuring of the mass loss of the cement due to solubility. Distilled water was used as a solvent. The measuring of every sample weight was performed before and after immersing in solvent for 1, 7, 14 and 21 days and mass loss was calculated as a percent of initial weight of the sample.

According to the results, the mass loss of selected cements after immersion in distilled water for the initial 24 hours period was $0.28 \%$ for ZP cement, $0.32 \%$ for RG, $0.51 \%$ for PC and $0.57 \%$ for GI cement. After this period, the mass loss decreased and was minimal at the end of the third week.

The precise evaluation of this basic characteristic is necessary for predicting clinical behavior of the permanent cement and the exact cement selection in every single case.
\end{abstract}

Keywords: permanent cementation, dental cement, solubility, dissolution

\section{Introduction}

The process of fixed prosthetic restoration consists of consecutive clinical and laboratory procedures finishing with cementation which provides strong and long integration between 2 different structures - the abutments and the artificial prosthetic construction. Permanent fixed prosthetic luting cements are the materials used for providing such integration. Usually they are consisted of 2 components: powder/liquid or base paste/activator (catalyst). Among other characteristics, the permanent cements used for fixation must exhibit structural stability and degradation resistance because, in the region of gingival finish line, they are exposed to potential dissolution caused by different oral fluids.

Although evolution in dentistry is mostly connected to constant improvement of dental materials and instruments, the everyday practice shows that part of these

\footnotetext{
*gigovski@hotmail.com
} 
improvements cannot be qualified as a real progress (Yearrn, 1987). The same statement refers also to permanent cements because the improvement of some physical characteristics not always results in better clinical performances (Diaz-Arnold et al., 1991; Donovan and Cho, 1999). That is why the constant reevaluation is needed and the attention has to be focused especially upon the cements properties which can cause potentially negative clinical implications. One of them is solubility and disintegration of the cement caused by the oral fluids. All actual types of permanent cements exhibited solubility, erosion, disintegration and mass loss when exposed to fluids for prolonged time. Dissolution of permanent cement due to solubility will affect the longterm retention of fixed prosthetic construction or, at least, it will degrade the hermetic obturation in the region of crown margin which may lead to microleakage with consequent bacterial invasion of the gap (Jacobs and Windeler, 1991).

The cement disintegration occurs due to diffusion of the soluble components of cement matrix in oral fluids and erosion of the unreacted powder particles disseminated in the same solid matrix.

The early testing methods for estimating the permanent cements solubility and dissolution dated for more than 50 years ago. Concerning the potential negative clinical effect of dissolution of the cement film, ANSI/ADA published the specification which limited the amount of solubility to $0.2 \%$ for 24 hours (Revised American National Standards Institute/American Dental Association Specification No. 8 for Zinc Phosphate Cement. JADA, 1988). International Standard's Organization (ISO) and other national organizations established for the control of instruments and materials in dentistry also standardized and allowed the same amount of solubility in all types of permanent dental cements (International Standard ISO No.7489, 1986; International Standard ISO No.1566, 1987).

According to ADA/ANSI revised specification, the recommended method for evaluation of the solubility of the cementing material is through measuring the weight of the cement sample before and after it was immersed in the solvent for the period of 24 hours and calculating the percent of its mass loss. The samples are in the shape of discs with specified dimensions.

Since the publishing of these standards, every dental cement which failed to meet the result of $0.2 \%$ cannot be considered for clinical use.

Chemical composition of the solvent (saliva, distilled water, acid solutions, organic-buffer solutions etc.) has a significant influence upon the result of the solubility testing (Ozcan et al., 2000). Especially aggressive are the low $\mathrm{pH}$ solutions (acids) provoking not only dissolution but also cement erosion when used for testing as a solvent. The dissolution and erosion depth of cement increased with decreasing the $\mathrm{pH}$ of the solvent (Eisenburger et al., 2003).
Although useful for quality control, the main objections of this in vitro test-method for measuring the cements solubility are that it gives an imperfect result due to 2 inconsistencies: the early attack of the aqueous solvent in the initial period when the cement is still hardening (the matrix is not fully formed) and the short time of exposition to solvent which is opposite compared to clinical practice. Because of these reasons, the testmethod does not enable correct predictability and longterm extrapolations of cement solubility in real clinical conditions (Wilson, 1976).

A significant reduction in erosion rate and solubility were confirmed in cases when testing the hardened cement samples started after some period of time. Reduction due to maturing was significant in dental cements with polymeric acids as a liquid component (Williams et al., 1992).

The clinical predictability of in vitro test methods is not yet completely determined because the process of cement dissolution is complex and consists of sequences of absorption, disintegration and solution. Many factors, such as type of the cement, thickness of the cement layer, molarity and $\mathrm{pH}$ of the medium, affect the degradation speed (Mesu, 1982).

To overcome this disadvantage, few authors used a method more similar to clinical conditions by inserting the particles of different cements into the small chambers fabricated in removable denture or crown and measured the mass loss of the inserted cement pieces after 6 and 12 months (Hersek and Canay, 1966; Phillips et al., 1987).

The samples of different permanent cements were also placed in holes located on the proximal surfaces of the golden crowns for the period of 6 months (Osborne et al., 1978).

These in vivo test-methods, although complicated and not suitable for quick laboratory testing, are more accurate for investigating the time-depending dynamic of solubility.

The aim of the study is to investigate the dynamic of solubility in different types of permanent cements during a prolonged time of exposure to the solvent.

\section{Materials and methods}

The solubility of 4 different types of permanent cements was investigated: zinc phosphate - ZP ("Harvard", Richter-Hoffman, Berlin, Germany), glass ionomer - GI ("Ketac CEM", Espe, Seefeld, Germany), reinforced resin-modified glass-ionomer - RG ("Fuji Plus", GC Corporation, Tokyo, Japan) and polycarboxylate cement - PC ("Harvard CC", RichterHoffman, Berlin, Germany). Totally 120 samples, equally divided in 4 series of 30 samples for every type of cement were fabricated. The samples were in the shape of discs with diameter of $20 \mathrm{~mm}$ and $2 \mathrm{~mm}$ high. Distilled water 
was used as a solvent. The weight of every sample was measured after immersion in the solvent for period of 1, 7, 14 and 21 days. Precise digital balance (E. Mettler, Zürich, Schweiz) with minimal resolution of $0.00001 \mathrm{~g}$ was used for measuring the weight of every sample. Prior every measuring, the samples were heated for 2 hours at temperature of $110{ }^{\circ} \mathrm{C}$ and stored in vacuum desiccation unit for evaporate and eliminate the residual water.

The percent of a mass loss of every sample before and after immersion in the solvent was measured. A mean mass loss of all 30 samples in the series was calculated as a percent of initial mean weight representing the solubility of the type of permanent cement used for fabrication of specific series.

\section{Results}

The obtained results confirmed the well-known data that investigated dental cements exhibit a relatively small loss of mass $\left(\Delta \mathrm{m}_{1}\right)$ when exposed to distilled water for the 24 hours period: $0.28 \%$ for $\mathrm{ZP}$, $0.32 \%$ for RG, $0.51 \%$ for PC and $0.57 \%$ for GI (Table 1). But although small, according to these results, the amount of solubility and degradation of all cements is higher compared to ADA/ANSI standard which allows $0.2 \%$ for 24 hours.

Table 1. Solubility measured as a percent of mass loss $(\Delta \mathrm{m})$ of evaluated cements after exposing (immersing) to solvent for period of $1(\Delta \mathrm{m} 1)$, $7(\Delta \mathrm{m} 7), 14(\Delta \mathrm{m} 14)$ and $21(\Delta \mathrm{m} 21)$ days

\begin{tabular}{ccccc}
\hline \hline & ZP & GI & RG & PC \\
\hline$\Delta \mathrm{m}_{1}(\%)$ & 0.28 & 0.57 & 0.32 & 0.51 \\
$\Delta \mathrm{m}_{7}(\%)$ & 0.86 & 0.97 & 0.73 & 1.21 \\
$\Delta \mathrm{m}_{14}(\%)$ & 1.05 & 1.23 & 0.91 & 1.52 \\
$\Delta \mathrm{m}_{21}(\%)$ & 1.15 & 1.35 & 0.99 & 1.50 \\
\hline
\end{tabular}

The additional fact which can be seen from the result is that the daily mass loss due to solubility is time-depending and slowly decreased during next 3weeks period (Fig. 1).

\section{Discussion}

The physical postulates and Fick's first law of diffusion state that the amount of dissolution in static conditions depends of the concentration gradient and the diffusion constant specific for the testing material and the solvent. Additional factors that affect the solubility are the size of exposed cement surface area, $\mathrm{pH}$ of the solvent, volume and composition of the solvent etc.

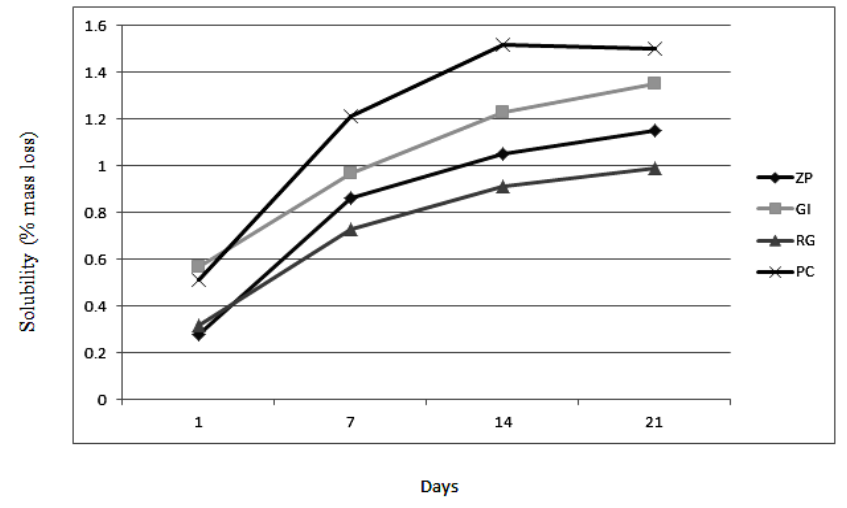

Fig. 1 Solubility $\Delta \mathrm{m}(\%)$ of evaluated cements after exposing (immersing) to solvent for period of $1,7,14$ and 21 days.

According the results of this investigation, the position range for solubility and disintegration of dental cements for the initial period of 24 hours is: zinc phosphate ( $\mathrm{ZP}$ ) less then resin-modified glass-ionomer (RG) less than polycarboxilate (PC) less then glass-ionomer (GI). In all investigated cements were measured higher values compared to recommended standard. In the literature there are both similar and opposite data and range. It was reported that the most soluble type of cement is GI (1\%), followed by PC $(0.6 \%)$ and $\mathrm{ZP}$ cement $(0.2 \%)$. The author of the investigation also published that solubility and disintegration of the same type of cement depend of the quality of the brand - different brands of zinc phosphate cement showed mass loss between $0.04 \%$ and $3.3 \%$ (O'Brien, 2002). The results of $0.05 \%$ for PC, $0.07-0.4 \%$ for RG and $0.4-1.5 \%$ for GI are also presented (Wassell et al., 2002). Another study stated that PC is the most sensitive cement type to dissolution and RG is the most stable (Jones, 1998). The prolonged duration of exposure of cement samples to the solvent had 2 effects: change in the range of the cements and decreasing of the solubility in all investigated cements. After 3 weeks immersing, RG was the list soluble $(0.99 \%$ mass loss) and PC exhibited the highest mass loss $(1.50 \%)$. The most noticeable result is the decreasing of mean daily mass loss related to prolongation of the period of immersion. The stabilization of cement samples and slow decreasing of solubility and disintegration is opposite and confronts the Fick's law. According to an investigation which reported about this time-depending relation, phosphate cement exposed to solvent immediately after hardening exhibited a mass loss of $3 \%$ for 24 hours, but if the exposition started after 48 hours, the mass loss was decreased to $0.2 \%$. In order to minimize the solubility, the author also pointed that mixing of the cement had to be done using powder/liquid ratio with maximal recommended amount of powder component (Eichner, 1981).

The structure of the hardened cement offers a possible explanation for the phenomenon of time-depending solubility. During the process of mixing and setting of the cement small amount of powder remains unreacted. This 
unreacted powder, in a shape of multiple nuclei, can be found on the surface and inside the cement matrix (Jorgensen, 1960). The high percent of a mass loss during the initial period probably occurs as a result of wash-out of the superficially positioned nuclei which are not fully embedded in the solid matrix. Once these nuclei of powder are washed away, the mass loss decreased because the cement matrix is more resistant and less soluble. Incongruent dissolution with leached particles derived by surface wash-out is also reported (Kuhn and Wilson, 1985).

The conclusion that zinc oxide dissolves leaving a "spongy matrix" is confirmed by cryo-SEM images showing many holes in the surface of hardened cement specimens after their exposition to jet of low $\mathrm{pH}$ solution (Nomoto et al., 2003).

A marginal leakage of cast gold crowns luted with zinc phosphate cement could be connected with a dissolution of the cement in the finish line region (Kydd et al., 1996).

\section{Conclusion}

According to the aims of this investigation and obtained data, it may be concluded that solubility and disintegration $(0.28 \%$ for ZP, $0.57 \%$ for GI, $0.32 \%$ for RG and $0.51 \%$ for PC) measured as a percentage of mass loss in the period of 24 hours exposure to the solvent in all investigated different types of permanent cements are higher compared to recommended ANSI/ADA standard of $0.2 \%$.

After the initial period of 24 hours, mass loss due to solubility slowly decreased and during the third week the process was stabilized and the solubility was minimal.

If the result of total mass loss for 21 days period for every cement is calculated in order to obtain the average daily solubility, all investigated cements exhibit solubility below the prescribed standard of $0.2 \%$.

\section{References}

Diaz-Arnold, A.M., Vargas, M.A., Haselton, D.R., 1991. Current status of luting agents for fixed prosthodontics. J. Prosthet. Dent. 81(2), 135-141. Available at: https://doi.org/10.1016/s0022-3913(99)70240-4.

Donovan, T.E., Cho, G.C., 1999. Contemporary evaluation of dental cements. Compend Contin. Educ. Dent. 20(3), 197199, 202-208.

Eichner, K., 1981. Zahnartztliche werkstoffe ind ihre verarbeitung. Dr. Alfred Hutig Verlag, Heidelberg, Germany.

Eisenburger, M., Addy, M., Rossbach, A., 2003. Acidic solubility of luting cements. J. Dent. 31(2), 137-142. Available at: https://doi.org/10.1016/s03005712(03)00002-2.

Hersek, N.E., Canay, S., 1966. In vivo solubility of three types of luting cements. Quintessence Int. 27(3), 211-216.
International Standard ISO No. 1566: Dental zinc phosphate cements. 1987.

International Standard ISO No. 7489: Dental glass polyalkenoate cements. 1986

Jacobs, M.S., Windeler, S.A., 1991. An investigation of dental luting cement solubility as a function of the marginal gap. J. Prosthet. Dent. 65, 436-441. Available at: https://doi.org/10.1016/0022-3913(91)90239-s

Jones, D.W., 1998. Dental cements: a further update. J. Can. Dent. Assoc. 64(11), 788-789.

Jorgensen, K.D., 1960. Structure of the film of zinc phosphate cements. Acta Odontol. Scand. 18, 491-498. Available at: https://doi.org/10.3109/00016356009043880.

Kuhn, A.T., Wilson, A.D., 1985. The dissolution mechanisms of silicate and glass-ionomer dental cements. Biomaterials 6(6), 378-382. Available at: https://doi.org/10.1016/01429612(85)90096-1.

Kydd, W.L., Nicholls, J.I., Harrington, G., Freeman, M., 1996. Marginal leakage of cast gold crowns luted with zinc phosphate cement: An in vivo study. J. Prosthet. Dent. 75(1), 9-13. Available at: https://doi.org/10.1016/01429612(85)90096-1.

Mesu, F.P., 1982. Degradation of luting cements measured in vitro. J. Dent. Res. 61(5), 665-672. Available at: https://doi.org/10.1177/00220345820610050901.

Nomoto, R., Uchida, K., Momoi, Y., McCabe, J.F., 2003. Erosion of water-based cements evaluated by volumetric and gravimetric methods. Dent. Mater. 19(3), 240-244. Available at: https://doi.org/10.1016/S01095641(02)00036-2.

O'Brien, W., 2002. Dental materials and their selection. Quintessence Publishing Co, Inc. Quintessence Books.

Osborne, J.W., Swartz, M.L., Goodacre, C.J., Phillips, R.W., Gale, E.N., 1978. A method for assessing the clinical solubility and disintegration of luting cements. J. Prosthet. Dent. 40(4), 413-417. Available at: https://doi.org/10.1016/0022-3913(78)90123-3.

Ozcan, M., Gemalmaz, D., Yorus, B., 2000. Determination of mechanism for erosion of glass-ionomer cements in organic-buffer solutions. 5th Congress of the Balkan Stomatological Society (Abstracts), Thessaloniki, Greece. 13-16 April, 125.

Phillips, R.W., Swartz, M.L., Lunds, M.S., Moore, B.K., Vickery, J., 1987. In vivo disintegration of luting cements. J. Am. Dent. Assoc. 114(4), 489-492. Available at: https://doi.org/10.14219/jada.archive.1987.0093.

Revised American National Standards Institute / American Dental Association Specification No. 8 for Zinc Phosphate Cement, 1988. JADA, 117, 843-848.

Wassell, R.W., Barker, D., Steele, J.G., 2002. Crowns and other extra-coronal restorations: try-in and cementation of crowns. Br. Dent. J. 193(1), 17-28. Available at: https://doi.org/10.1038/sj.bdj.480147.

Williams, J.A., Billington, R.W., Pearson, G.J., 1992. The effect of maturation on in-vitro erosion of glass-ionomer and other dental cements. Br. Dent. J. 173(10), 340-342.

Wilson, A.D., 1976. Specification test for the solubility and disintegration of dental cements: a critical evaluation of its meaning. J Dent Res. 55(5), 721-729. Available at: https://doi.org/10.1177/00220345760550050401.

Yearn J. A., 1987. The implications of assessment criteria for the dental industry. Quintessence Int. 18(8), 553-557. 
Резиме

\title{
Временски зависна растворливост кај различни фикснопротетички перманентни цементи
}

\author{
Никола Гиговски $^{1 *}$, Весна Коруноска Стевковска ${ }^{1}$, Анета Мијоска $^{1}$, \\ Сања Панчевска ${ }^{1}$, Емилија Ваљакова Бајрактарова ${ }^{1}$, Ана Гиговска Арсова ${ }^{2}$ \\ ${ }^{1}$ Катедра за стоматолошка протетика, Факултет за Дентална Медицина, \\ Универзитет „Св. Кирил и Методиј”, Мајка Тереза 43, 1000 Скопје, Р. Македонија \\ ${ }^{2}$ Стоматолошка ординација „Дента Нова”, Дебарияа 70, 1000 Скопје, \\ Р. Македонија
}

Клучни зборови: цементирање дефинитивно, цемент дентален, растворливост

Растворливоста на денталните цементи е значајна особина заради нивната пролонгирана изложеност на дејството на оралните течности. Препорачаниот стандард изнесува 0,2\% загуба на маса за перод од 24 часа.

Цел на истражувањето е да се измери растворливоста кај различни видови перманентни фикснопротетички цементи и нејзината зависност од долготрајноста на изложеност на цементот на дејството на растворувачот.

Испитувани се 4 видови цементи: цинк фосфат (ЦФ), глас-јономер (ГЈ), смолесто-модифициран глас-јономер (СГ) и поликарбоксилатен (ПК) цемент. Вкупно 120 примероци, поделени во 4 еднакви серии, беа фабрикувани во согласност со експерименталниот метод кој се користи за in vitro лабораториско мерење на загубата на маса на цементот предизвикана заради негово растворање. Како растворувач се употреби дестилирана вода. Мерење на тежината на секој примерок се направи пред и по потопувањето во растворувачот во временски интервал од 1,7 , 14 и 21 ден, а загубата на маса се пресмета како процент од иницијалната тежина на примерокот.

Кај селектираните видови цементи по нивното држење во дестилирана вода во период од 24 часа беше измерена загуба на маса од $0,28 \%$ кај ЦФ, $0,32 \%$ кај СГ, 0,51\% кај ПК и 0,57\% кај ГЈ цементот. По овој период, загубата на маса постапно стагнираше и на крајот на третата недела нејзиниот износ беше минимален.

Прецизната евалуација на оваа базична карактеристика е неопходна за да се предвиди однесувањето на перманентниот цемент во клинички услови и да се селектира соодветниот вид за секој поединечен случај. 
